\title{
Banding patterns in plant chromosomes. II. Bibliography (1970-1980) - Anthophyta. Supplement 2
}

\author{
MARTA MIZIANTY
}

Institute of Botany, Polish Academy of Sciences, Lubicz 46, 31-512 Kraków, Poland (Received: January 15. 1985. Accepted: January 21, 1985)

\section{Abstract}

The present paper complements the main bibliography (8) and Supplement 1 (9). It contains list of 4 plant species and appropriate literature for it.

Key words: bibliography. banding patterns, Anthophyta

\section{INTRODUCTION}

This supplement is constructed identically like main part of bibliography (8) and supplement 1 (9).

All explanations are given in the main part of bibliography (8).

Hordeum sp.

Nothoscardum fragrans

Rumex acetosa

Trillium ovatum
Giem. 2, 4, 5,

Giem. C-band 3

6,7 ,

Giem. C-band 10

Orc

11

\section{REFERENCES}

1. Fukuda I., Channell R. B., 1975. Distribution and evolutionary significance of chromosome variation in Trillium ovatum. Evolution 29: 257-266.

2. Linde-Laursen J., 1975. Giemsa banding of barley chromosomes. Barley Genetics Newsletter 5: 26.

3. Linde-Laursen J., 1976. Giemsa C-banding of barley chromosomes. (Abstract). In: Proc. 3rd International Barley Genetics Symposium. Garching. p. 304. 
4. Linde-Laursen J., 1976. Identification by Giemsa staining of the barley chromosomes and their arms. Barley Genetics Newsletter 6: 41-43.

5. Linde-Laursen J., 1976. Identification of the chromosomes of barley by Giemsa staining. (Abstract). Hereditas 84: 245.

6. Linde-Laursen J., 1978. Banding of barley chromosomes. Barley Genetics Newsletter 8: 74-76.

7. Linde-Laursen J., Olsen 0.-A., 1976. Identification of an interchange between chromosomes 2 and 5 in Risö mutant 56-a high lysine line. Barley Genetics Newsletter 6: 43-44.

8. Mizianty M., 1984. Banding patterns in plant chromosomes. II. Bibliography (1970-1980) Anthophyta. Acta Soc. Bot. Pol. 53: 111-136.

9. Mizianty M., 1984. Banding patterns in plant chromosomes. II. Bibliography (1970-1980) Anthophyta. Supplement 1. Acta Soc. Bot. Pol. 53: 485-487.

10. Sato S., Kuroki Y., Ohta S. 1979. Two types of color-differentiated C-banding positive segments in chromosomes of Nothoscardum fragrans, Liliaceae. Cytologia (Tokyo) 44: $715-725$.

11. Váňa V., 1972. The localisation of heterochromatic segments in the chromosomes of Rumex acetosa. Preslia 44: 316-326.

Wzory prązkowe chromosomów roślinnych. II. Bibliografia (1970-1980)Anthophyta. Uzupelnienie 2

\section{Streszczenie}

Niniejsza praca jest drugim uzupełnieniem bibliografii (8). Skonstruowana jest identycznie jak dwa poprzednie zestawienia. Wszystkie wyjaśnienia są umieszczone w wyżej wspomnianej bibliografii. 